Article

\title{
Sustainability and Dimensions of a Nexus Approach in a Sharing Economy
}

\author{
Petra Schneider * (1), Lukas Folkens, Andreas Meyer and Tino Fauk \\ Department Water, Environment, Civil Engineering, and Safety, University of Applied Sciences \\ Magdeburg-Stendal, D-39114 Magdeburg, Germany; Lukas.folkens@outlook.com (L.F.); \\ andreas.meyer@hs-magdeburg.de (A.M.); Tino.Fauk@student.wk.hs-magdeburg.de (T.F.) \\ * Correspondence: petra.schneider@hs-magdeburg.de; Tel.: +49-391-886-4577
}

Received: 30 November 2018; Accepted: 1 February 2019; Published: 11 February 2019

check for updates

\begin{abstract}
Increasing global resource consumption puts the availability of natural mineral resources under significant pressure. One strategy to overcome this trend is the decoupling of economic growth and resource consumption and the application of circular economy approaches. These approaches aim at closing material cycles across sectoral boundaries. Beside these attempts, there are further options for action aimed at minimization of resource consumption through resource sharing approaches. This study investigates resource-saving potentials on different scales namely on a personal scale through sharing goods and services, but also in the frame of industrial symbiosis through sharing of secondary resources at a company scale. The environmental effects have been quantified using life cycle assessment examples for these two simulated cases. The results show for both resource consumption levels, resource savings potentials of up to 2 powers of ten, that can particularly be proven regarding the impact category 'fossil resource depletion'. The emergence of industrial symbiosis can be identified by six factors: Resource, government, economy, company, technology, and society. The cases simulated in the study are supported by empirical evidence from real-life examples, which consider the mentioned factors.
\end{abstract}

Keywords: nexus approach; resource consumption and efficiency; sharing economy

\section{Introduction}

The relationship between global resource consumption and economic growth has been controversially discussed in economic terms and reveals itself, for example, in the formulation of different economic disciplines and positions. In recent decades, the terms "ecological accounting" and "environmental economics" have emerged as those sub-disciplines in economics that are particularly dedicated to resource use. In this context, two basic economic-ecological positions over the past decades can be closely linked to these developments. However, some scientists are of the view that resource consumption and economic growth cannot be decoupled from one another and systemic change is therefore required to achieve long-term environmental goals (e.g., [1,2]). This position is summarized under the term "degrowth" and is based on the work of Gorz and Georgescu-Roegen et al. in the early 1970s (cited in [3,4]). On the other hand, there is the idea of "green growth", underlining that technological progress, efficient production strategies, and the use of environmental economic instruments such as the internalization of external effects, can succeed in decoupling economic growth from resource consumption [5-7]. The degrowth position is based on the assumption that ecological goals can only be achieved if the economic value added within prosperous economies is reduced $[1,2,8]$. Overall, the attitude is fundamentally characterized by the assumption that there is a causal link between economic performance and resource consumption [2]. Consequently, resource depletion can be reduced decisively if the economic performance of the respective economies decreases 
sufficiently. Georgescu-Roegen [9] justified the impossibility of decoupling economic growth and resource consumption by stating that the production of goods and services requires the use of energy. On the other hand, there is the concept of green growth, which negates the inextricably positive causal relationship between economic performance and resource consumption and even assumes that green growth can contribute to the realization of a negative correlation between the two variables [10]. This is justified by the fact that the reduction of resource consumption can be achieved with technical innovations, which ultimately induce economic growth [10]. These innovations can spread to other countries as positive external effects and thus increase the decoupling effect. The decoupling hypothesis is a central element of the green growth movement and can be regarded as a fundamental distinguishing feature of both positions $[5,11]$. To this end, the green growth movement makes use of various environmental economic instruments, of which the internalization of external effects is the most commonly known [12].

It is inherent to both positions that there is a demand for a transformation of the industrialized countries in order to achieve ecological goals (cf. e.g., $[6,7,13])$. Advocates of green growth adhere to existing markets in this respect, but want to optimize them to the extent that, for example, negative external effects are internalized. Representatives of the degrowth perspective, on the other hand, assume that many of the economic activities currently carried out in traditional markets will in future be performed outside established markets or in markets with a fundamentally different design. The specific design of these alternatives can bring manifold benefits. Essential to this understanding is the concept of the "commons" (a contraction of the "commons-based peer production"), according to Benkler [14]. For example, the specific design of a new way of transmitting goods continues to manifest itself in a sharing economy, although this does not necessarily mean that it is part of the degrowth movement. The sharing economy can follow both, degrowth and green growth ideology, depending on the intentions of the economic entities involved. Consequently, a distinction can be made between commercial and non-commercial sharing economies. Within the non-commercial sharing economy [12], the concept of collaborative consumption is important. In contrast to commons-based production, this can be explained by the fact that goods are not produced jointly, but are usually purchased on markets, for joint future use. Both ideas do not focus on ownership but on access to goods and resources, which is why Rifkin [15] speaks in this context of a transition to an access society. Furthermore, both concepts combine the fact that dependency on monetary income is reduced. Sharing approaches can be designed in different ways: Typically, a distinction can be made between peer-to-peer (P2P), business-to-consumer (B2C) and business-to-business (B2B) models [16]. As a result, the sharing economy itself is often defined divergently. Definitions include Rifkin [15], Demary [17], Wosskow [18], Sundararajan [19] and Weber [20]. This present study does not commit itself to any of the definitions, but regards the basic idea of sharing goods and services as an essential concept for meeting current and future shortages of raw materials. The Institute for Ecological Economy Research (IÖW) in Germany, among others, conducts current research on this topic [21]. In the latest publication, Ludmann [22] examined the ecology of sharing for the first time through a life cycle assessment. Life cycle assessments were calculated and evaluated in the areas of clothing, everyday mobility, and travel accommodation. It was shown that sharing does not automatically make sense from an ecological point of view. This is particularly true when sharing approaches increase overall consumption, which is why sustainable consumption patterns must be included in the debate. It was also explained that there is still great potential in sharing [23].

Berlina et al. [23] considered industrial symbiosis as a driver for green growth. Industrial symbiosis describes a business collaboration wherein residuals from one enterprise serve as inputs to another [23]. It was characterized as a core concept for the implementation of circular economy according to McDonough \& Braungart [24] in scientific and institutional literature (for instance [25-27]). In addition, the Circular Economy Action Plan of the EU urges to promote innovative industrial processes, including industrial symbiosis. In its revised proposals on waste, the Commission is proposing to clarify rules on byproducts to facilitate industrial symbiosis [28]. Chertow [29] defined 
industrial symbiosis as an engagement of traditionally separate industries and entities in a collaborative approach to resource sharing that benefits both the environment and the economy. Chertow \& Park [30] summarized a cooperative resource sharing of water, energy, and material by-products and wastes across organizations at the heart of industrial symbiosis, for both environmental and economic benefits.

Historically, increasing population growth has led to a scarcity of resources. Since the second energy transition around 1900, the global material and energy consumption increased continuously (Figure 1). More than 68 billion tons of raw materials were used worldwide in 2009 [31]. With a predicted world population of over 9 billion people in 2050 and rapid economic growth in newly industrializing countries, the demand for raw materials is further growing, resulting in a per capita consumption of raw materials that is currently about four times higher in industrialized countries than in less-developed countries [31]. On a global level, several types of mineral resources like phosphorous and sand have already become scarce, while the pressure on the resources is still increasing. In 2017, the European Commission published a communication on its list of Critical Raw Materials (CRMs), which features 27 raw materials with a high supply-risk and a high economic importance to which reliable and unhindered access is a concern for European industries and value chains (the process or activities by which a company adds value to an article, including production, marketing, and the provision of after-sales service).

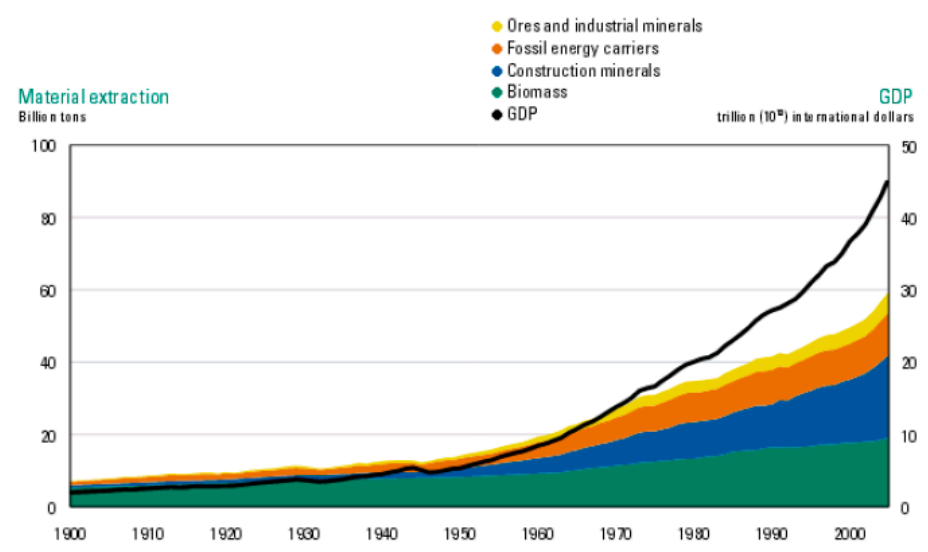

Figure 1. Resource consumption and global Gross Domestic Product (GDP) [31].

General strategies have been developed to foster resource efficiency and resource productivity in value chains, which have been increasing since heightened environmental awareness in the 1980s; see Figure 2.
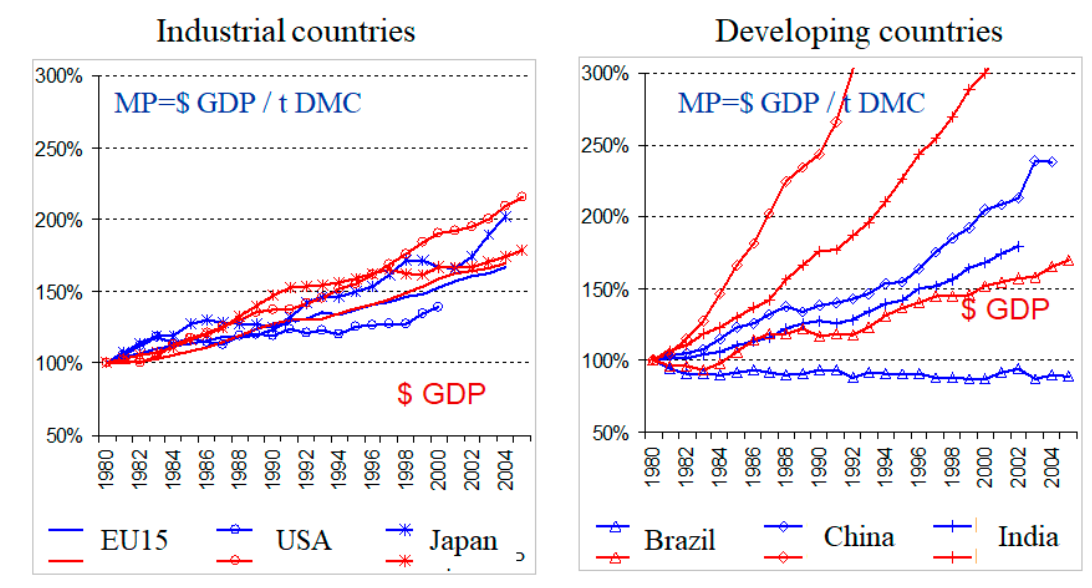

Figure 2. Trends in material productivity (MP) in relation to trends in \% increase in GDP, expressed in \$ GDP per ton Direct Material Input (DMC) [32]. 
To practice a circular economy does not only mean an understanding of the life cycle of a product, but also of the mechanisms of how to transform an end-of-life cycle into a circular life cycle. Improving resource productivity and ensuring sustainable resource and materials management based on the $3 R$ principle (reduce, reuse, recycle) is a central element of green growth policies [33,34]. 3R complementing approaches are integrated resource management strategies, like Integrated Solid Waste Management [35], Integrated Water Resources Management [36-38], Integrated Natural Resources Management $[39,40]$ as well as the inter-sectoral resource management strategies, namely the Water-Energy-Food Nexus [41-45], the Water-Soil-Waste Nexus [46], and the Minerals-Energy Nexus [47],while integrated resource management strategies focus on better management strategies inside one sector along a value chain, that is managing resource productivity. Nexus approaches, on the other hand, have more sectors in focus, which depend on the same type of resources and sometimes even on the same resource stock, which entails management of resource scarcity. This kind of dependency requires sharing available resources responsibly in order to avoid resource conflicts. Responsible resource use means not only the improvement of resource efficiency in the production process but also sharing of resources in order to increase resource productivity, closing unbalanced material cycles, and the promotion of responsible consumption.

Taking into account the global development of resource consumption and the existing approaches to managing resource productivity and scarcity, this study focuses on the investigation of the feasibility and efficiency of resource-sharing approaches. The potential for resource savings on a personal and company level were evaluated exemplarily. The investigation assesses resource-saving potentials on different scales, namely on a personal scale through sharing goods and services, as well as in the frame of industrial symbiosis through sharing of raw materials and secondary raw materials on a company scale. The environmental effects have been quantified using life cycle assessment examples for these two simulated cases. Two case studies were investigated to quantify resource savings through resource sharing approaches by: (a) common use of goods in a local goods sharing network, and (b) resource efficiency through the common use of resources and secondary resources through industrial symbiosis of innovative industries, particularly insect farming for human food production. According to the results of the literature review, life cycle assessments for industrial symbiosis with insect farming does not yet exist in the scientific literature. The number of LCAs for an application with insect farming is limited. Halloran et al. (2017) [48] highlighted that "the few existing studies that aim to evaluate the environmental performance of insect farming systems are extremely limited in scope". Already in 2016, Halloran et al. [49] underlined that the first study on LCA applied to insect farming for human consumption was published in 2012 by Oonincx \& de Boer [50], while the first LCAs related to insects as animal feed were published in 2015 by Roffeis et al. [51] and van Zanten et al. [52]. Insect farming for protein production has been considered in this study because of its outstanding potential for a future global food security. The study has been structured in a comprehensive literature review, providing the basics for the economic understanding of the resource sharing subject, followed by the description of the materials and methods, the presentation of the results of the assessment of the case studies, followed by the discussion and conclusions on the applicability of resource-sharing approaches.

\section{Materials and Methods}

\subsection{General Approach}

The investigations prepared for this article consist of a comprehensive literature review on resource-sharing approaches and an assessment of case studies. The theoretical part of this study follows a classical literature search, whereby an attempt has been made to present the topic as up-to-date as possible. The scope of the contribution is to quantify through presentation of examples the resource-saving potentials of sharing economy approaches in different dimensions and on different scales. Two case studies were investigated to quantify resource savings through resource-sharing approaches by: 
(a) Responsible private consumption through the common use of goods in a local goods sharing network: sharing resources on a household and communal scale.

(b) Resource efficiency through the common use of resources and secondary resources in company resource-sharing networks (i.e., sharing resources through industrial symbiosis).

The resource consumption of the sharing approaches (a) and (b) was assessed through a Life Cycle Assessment (LCA) according to ISO 14040 and 14044, comprising the steps Life Cycle Inventory (LCI) and Life Cycle Impact Assessment (LCIA). LCIA translates emissions and resource extractions into a limited number of environmental impact scores by means of so-called characterization factors. The aim of the model is to show, through an intentionally simplified example, how the emissions change when material flows are optimized through: (a) Industrial symbiosis and (b) when factories are combined. There are two common approaches to derive characterization factors, i.e., at midpoint level and at endpoint level. Midpoint indicators focus on single environmental problems, for example global warming change. Endpoint indicators indicate the environmental impact on higher aggregation levels, being: (1) The effect on human health, (2) biodiversity and (3) resource scarcity (National Institute for Public Health and the Environment of The Netherlands, 2018).

The databases that have been used are ProBas+ from the Federal Environment Agency Germany and ECLD from the Joint Research Center (JRC) of the European Commission. Both databases are open access (www.probas.umweltbundesamt.de/php/index.php; http://eplca.jrc.ec.europa.eu/ ELCD3/). Both databases are formatted by GreenDelta to be compatible with the OpenLCA software. The resulting data base for ProBas has over 30,000 data sets, which is suitable for use in LCA studies and with OpenLCA. The database contains a range of modern, up-to-date impact assessment methods tailored to the data sets. Most data sets are available as single processes as well as system processes. The ELCD database contains over 500 different processes from industrial sectors such as energy, materials production, and transport. The data sets are all available in English and mainly relate to Europe.

The methods used for impact assessment were ReCiPe Midpont $(\mathrm{H})$ and CED. In general, ReCiPe calculates 18 mean value indicators and 3 endpoint indicators and CED continues to calculate the energy demand along the whole process chain. For this LCA, characterization factors climate change, fossil depletion, marine eutrophication, particulate matter formation, photo chemical oxidation, terrestrial acidification, water abstraction, cumulative energy demand, and depletion of non-renewable resources. Details on the input and output data of the LCA can be found in the Supplementary Material to this study. The results of the LCIA are intended to illustrate the differences in the usage behavior of everyday objects and the individual use of facilities compared with a merger of production plants. In the first approach, the emissions of the individual household objects and installations have been broken down. Subsequently, a comparison has been made of the exchange of the objects and the merger of production plants.

\subsection{Sharing Resources on Household and Communal Scale}

The scope of this part of the study was to assess the resource-saving benefits from sharing common everyday objects (goods) at a household level in sharing communities like one's neighborhood. To compare the environmental impacts, six randomly selected everyday objects were selected and their life cycle impact compared. From the authors' point of view, these are objects that are needed from time to time, but which do not necessarily have to exist in each household. The considered objects are a dinghy, a wok, a ladder, a barbecue grill, a bicycle pump and a set of tools consisting of screwdrivers, a hammer and a folding rule. The LCA for each of these objects was calculated, assuming that each object shall be shared $6 \pm 2$ times a year. Due to the large number of possible combinations, assumptions were computed using a Monte Carlo simulation.

As usage, duration was considered a period of one year. Any associated effects such as rebound effect or higher wear were not included. This is due to the fact that it is almost impossible to obtain information on whether consumers purchase items themselves or not or how the items are used. 
However, this issue has a considerable impact on the life cycle assessment; therefore, the assumption is based on one year during which the item does not become obsolete. Furthermore, a local use is assumed, i.e., distances that can be covered by foot in order to not generate additional emissions. To find out where items can be borrowed, there is an ever-increasing number of websites and telephone apps that allow users to quickly and easily get in touch with each other.

\subsection{Sharing Resources through Industrial Symbiosis}

Industrial symbiosis is a concept within industrial ecology, focusing on enlarging sustainability in the economy, which became popular in the last decade. There does not yet exist in the literature a clear definition; however, the most comprehensive characterization was done by Boons et al. [53], based on the definition of Chertow [29], who summarized industrial symbiosis as "engaging traditionally separate industries in a collective approach to competitive advantage involving physical exchange of materials, energy, water, and by-products. The keys to industrial symbiosis are collaboration and the synergistic possibilities offered by geographic proximity". Boons et al. [54] went beyond that definition by including a competitive advantage through the exchange of physical substances as a complementing aspect as well as the consideration of social and geographical aspects. With this addition, the characterization of industrial symbiosis considers the common aspects of sustainability. The origin of the concept was laid by the municipality of Kalundborg in Denmark, where the first Eco Industrial Park started in the 1970s. Industrial Symbiosis enables companies to develop multilateral solutions for material and energy flows, thus overall reducing the ecological footprint. Industrial symbioses is a sharing approach by its nature. Typical industrial symbioses contexts are given in Boons et al. $(2011,2014)$ [53,54] and von Hauff (2012) [55], and refer to sharing of residues as secondary raw materials, sharing excess heat between companies, and infrastructure as well as network sharing. The linking mechanism inside industrial symbiosis can be a bilateral sharing, a cascade sharing or a sharing according to the nucleus principle, which refers to a central supplier of secondary raw materials as a core of an industrial symbiosis [56]. According to [57], the emergence of industrial symbiosis can be identified by six factors: Resource (resource scarcity and availability of waste), government (regulations and standards and financial support), economy (economic benefit, financial payback and new business opportunities), company (short mental distance, trust, security and awareness), technology (technology innovation) and society (social organization or support system).

An industrial symbiosis for the present investigation was designed using the nucleus principle [58]; in the present case, a waste incineration plant that produces secondary raw materials and excess heat. The model is based on data from studies by the Federal Environment Agency, the German Biomass Research Centre, the German Energy Agency, information from the Bavarian State Office for the Environment, product information from manufacturers and masters' theses from the University of Applied Sciences Magdeburg-Stendal. Scope of the industrial symbiosis investigation was to quantify the resource-saving effect and to compare it to an individual resource use. In order to compare the environmental impacts of individual plants with those of a merger of plants, a simple model was created for illustrative purposes. In the first step, four different commercial/industrial facilities were created. There relate to two office buildings, a factory for the production of plasterboard, an insect farming facility, and an aquaponics facility; see Figure 3. The supply of the buildings takes place through the public grid and depends on the energy mix for Germany. In the second case, the individual plants were connected to each other and amalgamated with two further plants. In addition, a waste treatment plant that can recycle the commercial waste and generate energy as well as a bio gas plant to recycle the organic residues are included. In order to be able to compare these results, comparable assumptions in terms of dimensions, materials and energy consumption, and production were made in both models. The environmental effects were quantified as examples through a life-cycle assessment for these two simulated cases. Furthermore, data from literature was used for the validation of the LCA of the industrial symbiosis with insect farming, particularly Marchi et al. [58], Smetana et al. [59] and Halloran et al. [49]. Industrial symbiosis was identified in the scientific and institutional literature as a 
core concept for the implementation of a circular economy; for instance, by Taranic et al. [25], Cui \& Lui [26], and Baldassarre et al. [27]. The Circular Economy Action Plan of the EU urges the promotion of innovative industrial processes including industrial symbiosis. In its revised proposals on waste, the Commission proposes a clarification of rules on byproducts to facilitate industrial symbiosis (EC, Closing the loop-An EU Action Plan for the Circular Economy, 2015). The assumed components of the industrial symbiosis are described below:
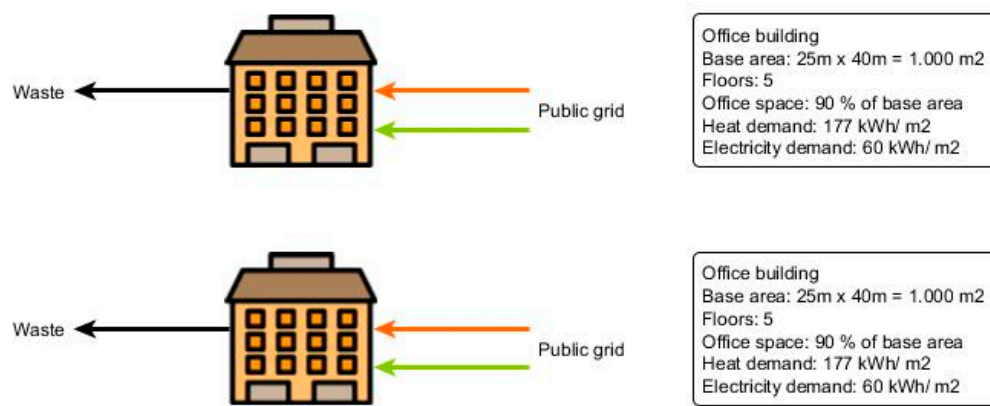

Office building

Base area: $25 \mathrm{~m} \times 40 \mathrm{~m}=1.000 \mathrm{~m} 2$ Floors: 5

Office space: $90 \%$ of base area

Heat demand: $177 \mathrm{kWh} / \mathrm{m} 2$

Electricity demand: $60 \mathrm{kWh} / \mathrm{m} 2$

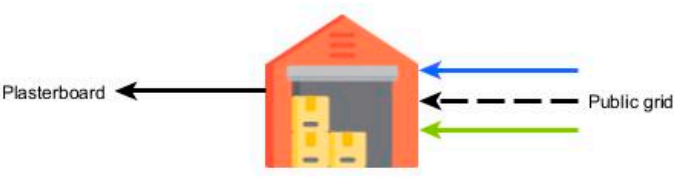

Plasterboards

Number: 78.495 pieces

Gypsum: $94 \%$

Water: $12 \%$

Cardboard: $3 \%$

New gypsum: $100 \%$

Heat demand: $19.24 \mathrm{kWh} / \mathrm{m} 2$ plasterboard

Electricity demand: $0.5 \mathrm{kWh} / \mathrm{m} 2$ plasterboar

Diesel: $0.037 \mathrm{kWh} / \mathrm{m} 2$ plasterboard

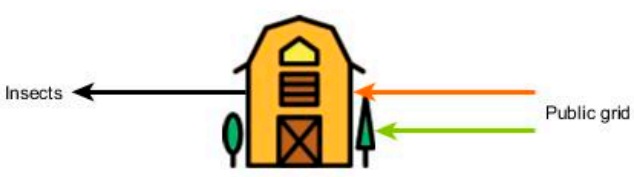

Insect farming

Building area: $850 \mathrm{~m} 2$

Heat demand: $78 \mathrm{MWh} / \mathrm{a}$

Elecricity demand: $241 \mathrm{MWh} / \mathrm{a}$

Insects production: $180.000 \mathrm{~kg}$
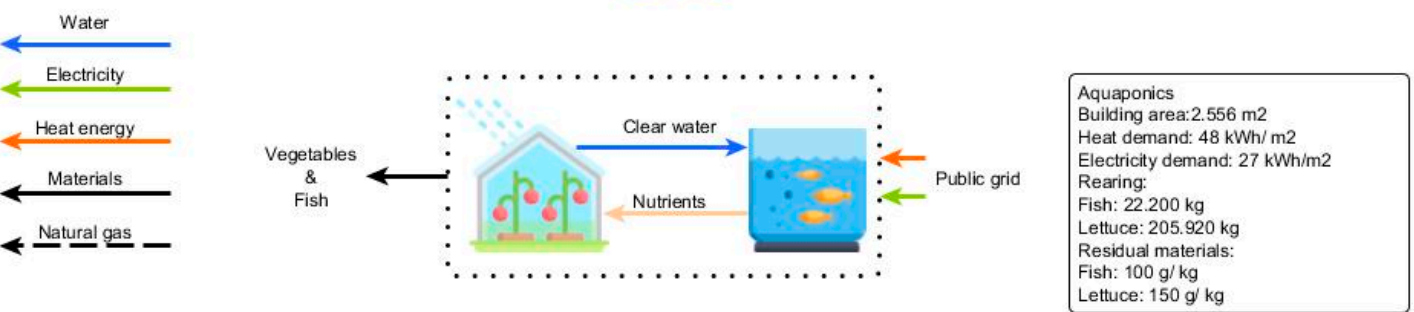

Figure 3. Example of individual systems that operate and are supplied separately; source icons: (https://www.flaticon.com/).

Office building: The building serves administration or service tasks. The spatial use ranges from single to multi-room office to conference rooms. Based on the available floor area, about $90 \%$ of the area can be used. The average energy consumption is around $177 \mathrm{kWh} / \mathrm{m}^{2}$ for heat and $60 \mathrm{kWh} / \mathrm{m}^{2}$ for electricity per year [60].

Plasterboard manufacturing: The main materials used in the production of plasterboard are gypsum, water, and cardboard. The production is mainly done by mixing the gypsum with water, application of the cardboard, and drying of the boards [61]. For the production of the gypsum board, the main part of gypsum can be either natural gypsum, as in the first case, or FDG (flue gas desulfurization) gypsum, as in the second example. A total of 78,495 plates are to be produced in the process.

Insect farming: In Europe, the production and marketing of insects as food in Europe is governed by the so-called "Novel Foods" legislation, i.e., Regulation (EU) No 2015/2283. Being permitted on the market through this legislation, insect farms started to be established particularly in Germany and Switzerland; they are feasible for industrial symbiosis due to their energy consumption, as they can use 
excess heat for insects farming. For the present case study of industrial symbioses, the chosen insect species are Gryllus assimilis and Tenebrio molitor. Gryllus assimilis is a cricket whose natural habitats are characterized by sub- or tropical climate. The temperature for the highest rate of reproduction is around $30^{\circ} \mathrm{C}$. The rearing of Gryllus assimilis is realized with special reactors [62]. A further species that is considered is Tenebrio molitor (also called mealworm, representing the larval stage of Tenebrio molitor). These insects have the highest rate of reproduction with an optimal breeding temperature around $27^{\circ} \mathrm{C}$. Larval rearing is realized in boxes that are stacked in shelves. Both types of insects do not really need daylight, so the number of lamps in the breeding building are set at a minimum consistent with work safety. The main electrical energy consumer is process technology. The building has a light metal roof and walls of concrete blocks including insulation. The floor area for insect breeding is about $850 \mathrm{~m}^{2}$. The operating height of the rearing building is approx. $4 \mathrm{~m}$. The produced insect biomass is around $180,000 \mathrm{~kg}$ per year. The heat demand is nearly of 78,000 $\mathrm{kWh}$ per year [62]. The electrical energy demand is approx. $241,000 \mathrm{kWh}$ in the same time frame. Fresh air for breeding is provided six times an hour. A heat exchanger transfers the heat from the exhaust air to the fresh air. The efficiency of the heat exchanger is valued at 0.4. The special reactors for rearing G. assimilis have a heat loss. This loss of thermal energy leads to the need to heat up the rearing room around the reactors. As a result, the electrical energy demand with focus on produced insect biomass in one year is $1.35 \mathrm{kWh}$ per kg biomass, and with reference to rearing space (this is the only sealed area in the building. The net rearing area is much larger than the sealed area, as the boxes are placed one above the other on shelves) is around $284 \mathrm{kWh}$ per $\mathrm{m}^{2}$ and year. The heat demand for produced biomass is around $0.44 \mathrm{kWh}$ per $\mathrm{kg}$ biomass and with reference to the sealed floor is $92 \mathrm{kWh}$ per $\mathrm{m}^{2}$ a year [62].

Aquaponics: From its basic concept, an aquaponics system is already a small industrial symbiosis. On the one hand, there is plant breeding by hydroponics to grow vegetables, while on the other, fish farming is aquaculture. The water within the system is circulated, i.e., permanently exchanged between the plants and fish. The polluted water from the fish breeding, caused by the excretions of the fish, provides nutrition to the plant system. In this way, the water is purified and then flows back to the fish. The operation of a system of approximately $2550 \mathrm{~m}^{2}$ can result in $22.200 \mathrm{~kg}$ fish and $205.920 \mathrm{~kg}$ vegetables (lettuce) per year. The resulting residues amount to $100 \mathrm{~g} / \mathrm{kg}$ fish excrements and dead fish, as well as $150 \mathrm{~g} / \mathrm{kg}$ plant remains. For this activity, $48 \mathrm{kWh} / \mathrm{m}^{2}$ of heat and $27 \mathrm{kWh} / \mathrm{m}^{2}$ of electricity is required [63-65].

The single model was expanded to include a waste incineration plant and a bio gas plant for methane production in order to combine the individual plants to form a complex; see Figure 4. In this way, the material flows can be optimally distributed and used within the system. Since industrial symbiosis is the connection of material flows in a small spatial area, the mutual exchange can be more efficient than with an individual approach. Partially, energy can be generated by the waste incineration plant from commercial waste of the office buildings. Within the waste incineration plant, gypsum is generated as a residual material during the cleaning and filtering of the gases; the resulting FDG gypsum can then be reused for the production of gypsum boards. Organic residues from the aquaponics, which are produced during the breeding of fish and plants, can be used as food for insects or for the production of bio methane. The organic residues from insect breeding can also be used for a bio gas plant. The obtained bio methane can be used to dry the gypsum boards during production. It is assumed that excess energy is not used in the symbiosis and can be provided to the public grid for distribution.

Waste incineration plant: The size of the waste incineration plant was dimensioned with a throughput capacity of 50,000 t/a. Measured in terms of throughput, this corresponds to the smallest waste incineration plant in Germany (state 2016) [66]. Waste has an average energy content of $8 \mathrm{MJ} / \mathrm{t}$ to $12 \mathrm{MJ} / \mathrm{t}$ and is assumed to be $10 \mathrm{MJ} / \mathrm{t}$ in the model. From the imported energy, $10 \%$ can be converted into electrical energy and $45 \%$ into thermal energy by thermal recycling. When the flue gases are cleaned, about $6.38 \mathrm{~kg}$ of gypsum per $1000 \mathrm{~kg}$ of waste is produced [67]. A waste incineration plant of 
$50,000 \mathrm{t}$ per year could produce far more electricity and heat and then release them into the public grid (see also Supplementary Material). The energy requirement of the other buildings was chosen as the upper limit for the calculation. Accordingly, the emission results are mainly influenced by the system boundary at each LCA.

Bio methane: Unlike bio gas, bio methane can be fed into the public natural gas grid to convert it into electricity or heat elsewhere. The size of the plant is dimensioned with a feed volume of $200 \mathrm{~m}^{3} / \mathrm{h}$, which corresponds to a small plant in Germany [68]. The quality requirements for the feed-in are at least $90 \%$ methane content in order to feed the bio methane into the natural gas grid [69]. This results in an energy content of $8.97 \mathrm{kWh}$ per cubic meter [70].

Plasterboard Manufacturing: The FDG gypsum from the waste incineration plant is completely processed for the production of the gypsum boards. The boards then consist of $49 \%$ FDG gypsum and $51 \%$ natural gypsum [71].
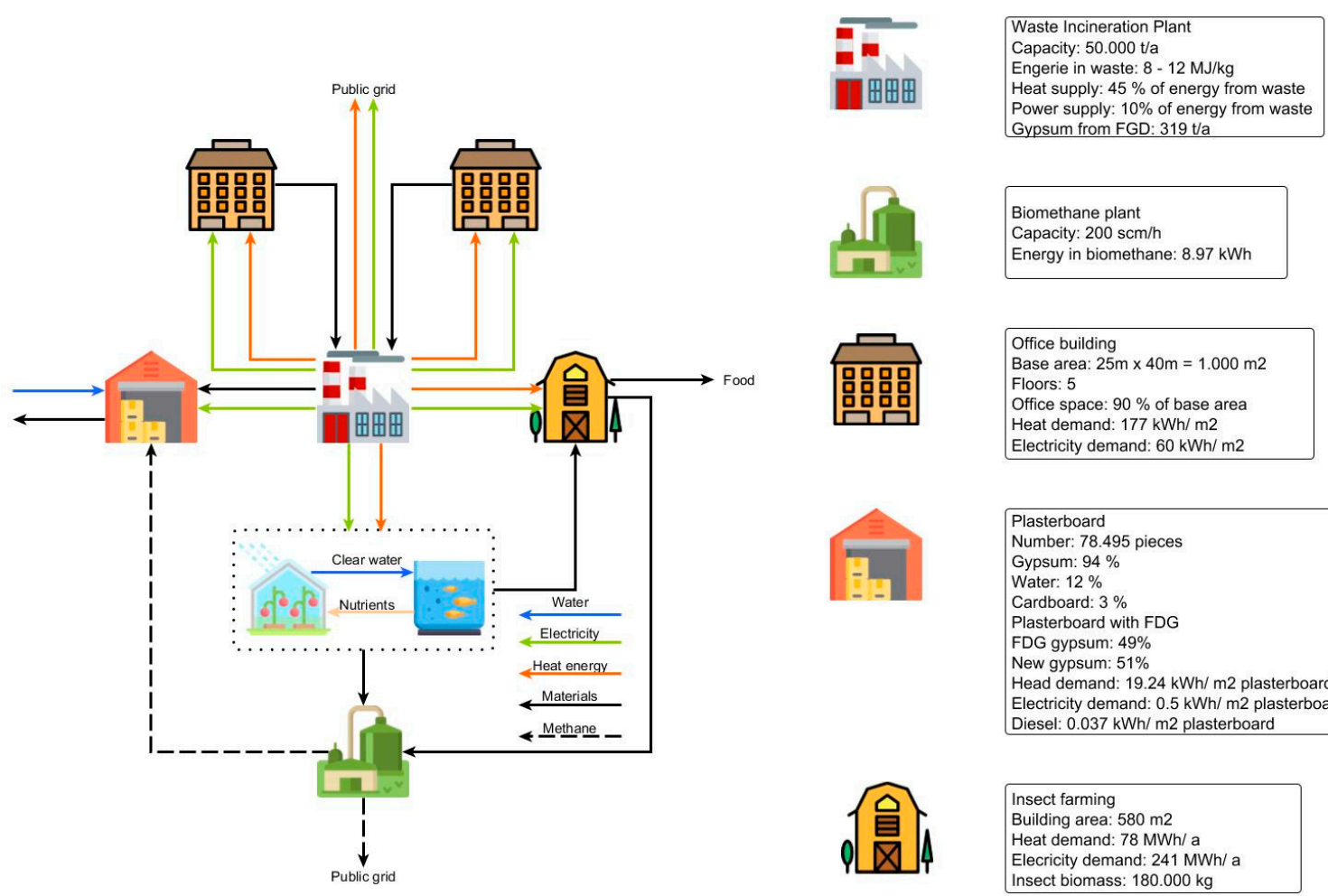

Heat supply: $45 \%$ of energy from waste
Power supply: $10 \%$ of energy from waste Gypsum from FGD: $319 \mathrm{t} /$

Biomethane plant Capacity: $200 \mathrm{scm} / \mathrm{h}$
Energy in biomethane: $8.97 \mathrm{kWh}$

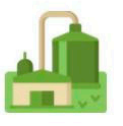
Energy in biomethane: $8.97 \mathrm{kWh}$

\section{Office building}

Base area: $25 \mathrm{~m} \times 40 \mathrm{~m}=1.000 \mathrm{~m} 2$

Floors: 5

Office space: $90 \%$ of base area

Heat demand: $177 \mathrm{kWh} / \mathrm{m} 2$

Electricity demand: $60 \mathrm{kWh} / \mathrm{m} 2$

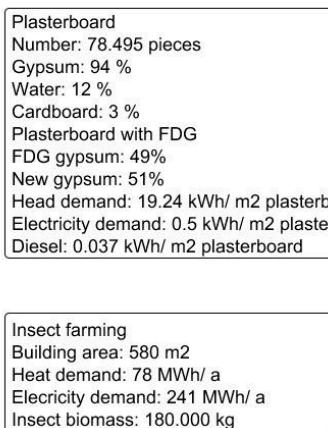

Elecricity demand: $241 \mathrm{MWh} /$
Insect biomass: $180.000 \mathrm{~kg}$

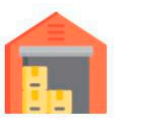

Aquaponics

Building area: $2.556 \mathrm{~m} 2$

Heat demand: $48 \mathrm{kWh} / \mathrm{m} 2$

Electricity demand: $27 \mathrm{kWh} / \mathrm{m} 2$

Rearing:

Fish: $22.200 \mathrm{~kg}$

Lettuce: $205.920 \mathrm{~kg}$

Residual materials:

Fish: $100 \mathrm{~g} / \mathrm{kg}$

Lettuce: $150 \mathrm{~g} / \mathrm{kg}$

Figure 4. Example of industrial symbiosis towards more efficient use of material and energy flows; Source icons: (https://www.flaticon.com/).

\section{Results}

\subsection{Sharing Resources on Household Level}

First, the environmental effects are shown that result for the life cycle of the respective objects which are individually used, followed by the results for the products' life cycle under collaborative use. In the second case, there are no further emissions, as these items are already physically present. 
Figure 5 shows the results of the life cycle impact assessment for each everyday household item. The results indicate that the life cycle of the products bicycle pump, barbecue grill and ladder cause the largest environmental impacts, followed by the tool set and the dinghy. All of these items use non-renewable resources, which lead to fossil fuel depletion.

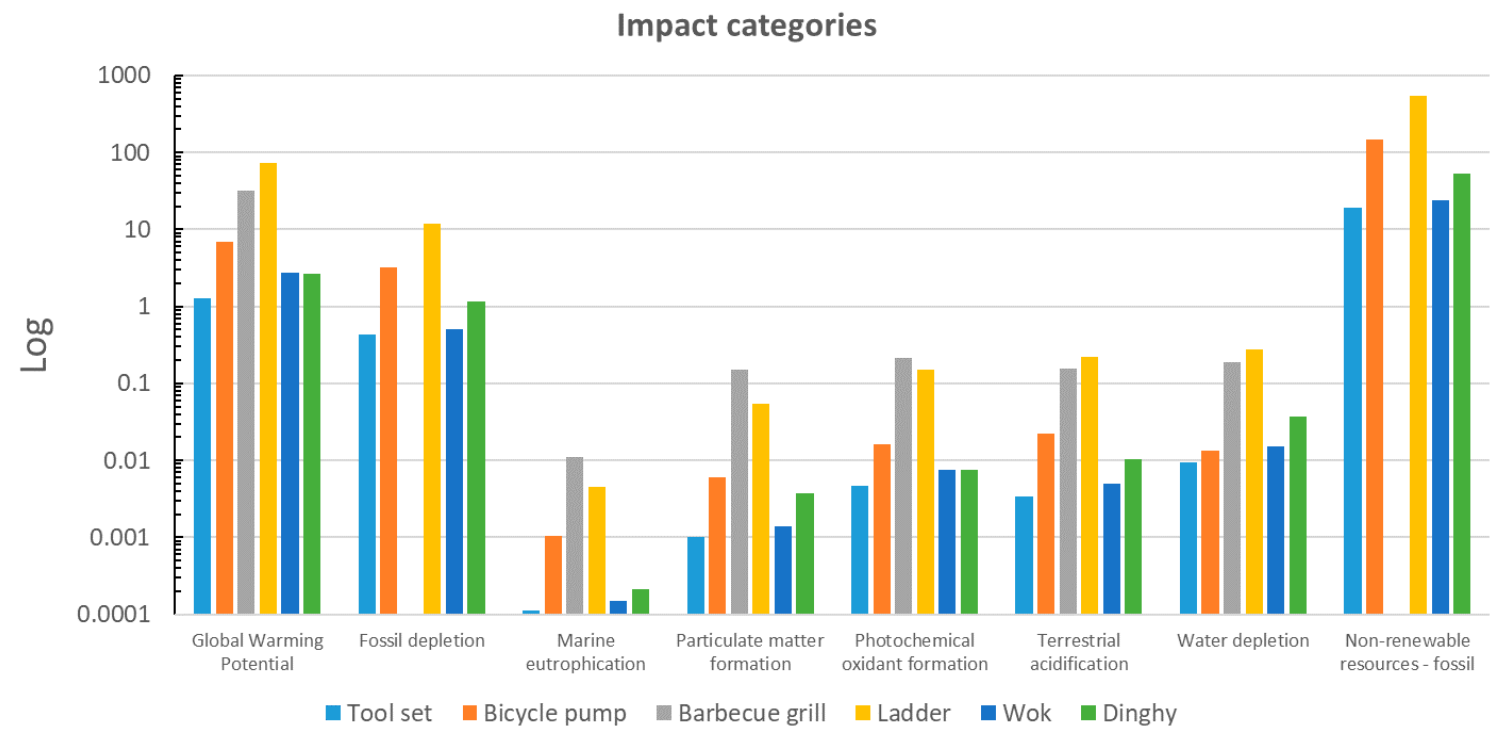

Figure 5. Results of the life cycle impact assessment for each everyday household item (for the barbecue grill are not available data for the impact assessment of the fossil fuel depletion and the consumption of non-renewable resources).

Figure 6 shows the results of the impact assessment as sum for all everyday household items, when they are individually used. Figure 7 shows the results of the Monte Carlo simulation for the environmental impact resulting from the use of shared everyday household objects.

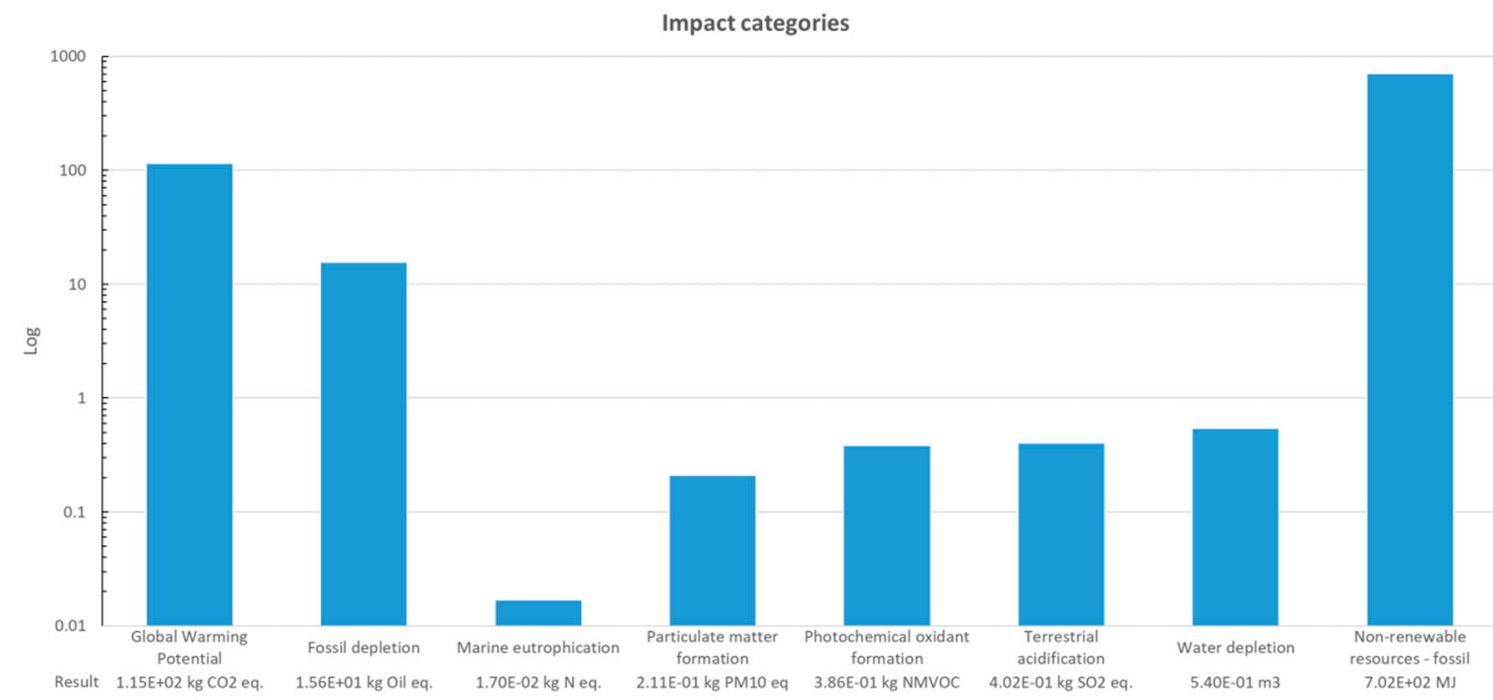

Figure 6. Results of the impact assessment as sum for all everyday household items, individually used. 


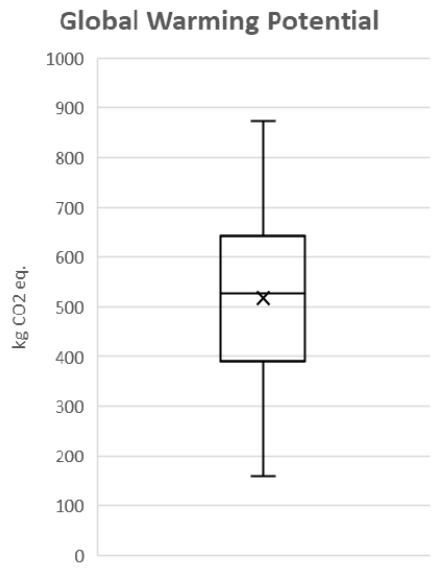

(a)

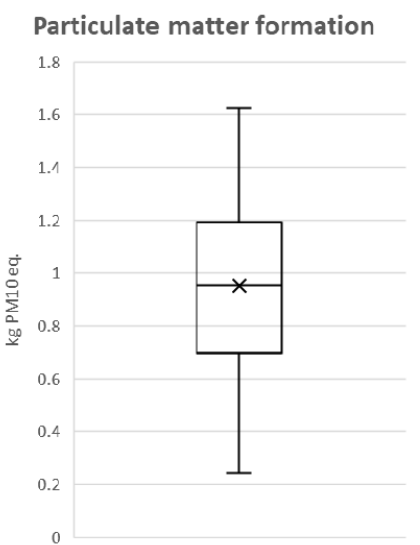

(d)

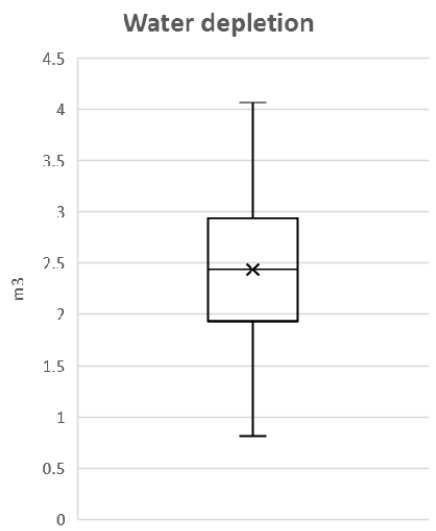

(g)

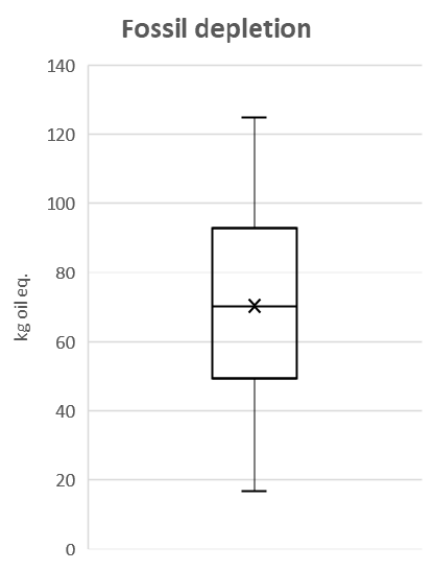

(b)

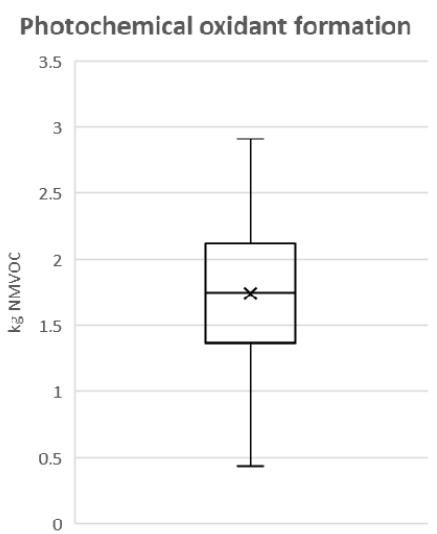

(e)

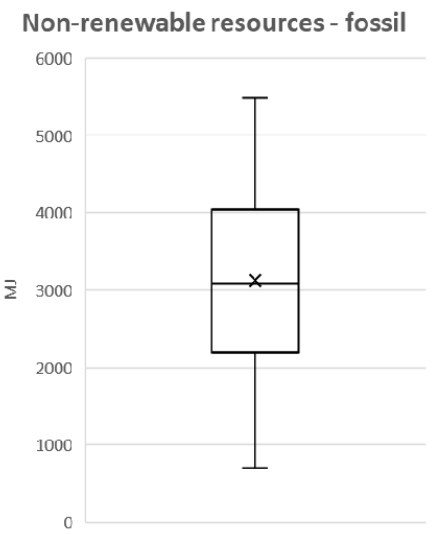

(h)

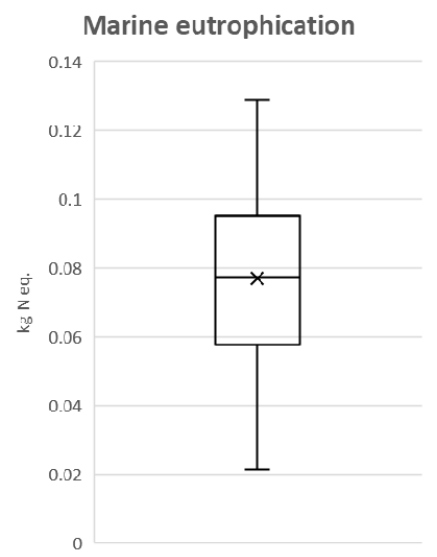

(c)

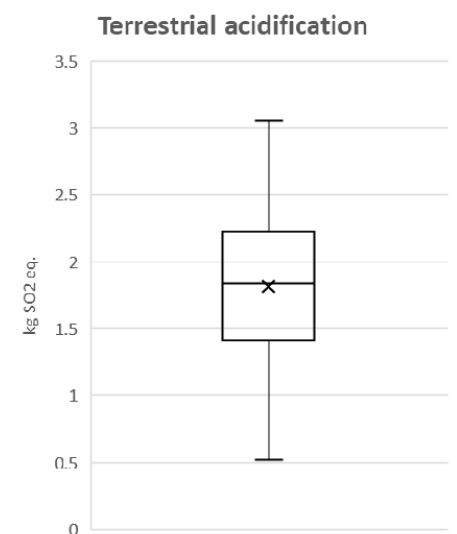

(f)

Figure 7. Result of the Monte Carlo simulation for the environmental impact resulting from the use of shared everyday household objects. (a) Global Warming Potential, (b) Fossil depletion, (c) Marine eutrophication, (d) Particulate matter formation, (e) Photochemical oxidant formation, (f) Terrestrial acidification, (g) Water depletion, (h) Non-renewable resources-fossil.

The results in Figure 6 show that in terms of climate change impact, expressed through the greenhouse effect, $115 \mathrm{~kg} \mathrm{CO}$ eq. are emitted altogether for all the everyday items during their life cycles. Furthermore, approximately $15 \mathrm{~kg}$ of fossil energy sources are needed for the production and the use of all the items. Out of the pure mass balance, $\mathrm{CO}_{2}$ eq. and fossil energy sources categories form the largest quantity of the total energy demand from fossil energy sources such as hard coal, natural gas and crude oil sums up to $702 \mathrm{MJ}$ along the value chain. The results shown in Figure 7 are 
obtained, assuming that all six household items are shared on average six times per year, plus minus two times. It can be seen from the individual illustrations of the impact categories that the emission values range widely between the minimum value and the maximum value. This mainly depends on how often the objects are shared. The sharing ranges from an object that is shared only a few times to all objects that are shared often. However, it becomes also obvious that the more often objects are shared, the higher becomes the resource savings potential leading to a decrease of the environmental impact as no new objects have to be produced.

The results support the assumptions of Georgescu-Roegen [4] regarding the impossibility of decoupling economic growth and resource consumption as the production of goods and services requires the use of energy. Therefore, it becomes obvious that the environmental impact is significantly lower if in the production of the objects uses renewable rather than fossil fuel energy. According to the energy conservation law, the use of fossil energy resources leads inevitably to greenhouse gas emissions, while renewable energy use focuses on an energy use free of residues. In the present case, it can be shown that the shared use of goods leads to a decreased consumption of resources and a reduced economic growth as less new products are sold. This conclusion on collaborative consumption complies with the considerations of Georgescu-Roegen [4].

Resource savings increase exponentially with the number of shared usage processes, but there is a limit to the extent of the shared use in the system. It must be taken into consideration that a very frequent use of the items leads to faster wear, which may result in the need for an earlier replacement purchase. This leads to the conclusion that for a sensible multiple use of objects, a better quality of goods must be ensured, in particular with regard to the longevity of the products as is the scope of eco-design. Eco-design is a systematic and comprehensive design approach for products to reduce environmental impact through life cycle design through improved product design. Eco-design's goal is to find environmentally sound solutions in an integrated life-cycle analysis in order to reduce the overall environmental impact of a product. It therefore supplements the classic requirements for product development, such as functionality, safety, ergonomics and price/performance ratio, with the requirement of environmental friendliness. Eco-design is thus a comprehensive design task of sustainable corporate management. With the Eco-design Directive 2009/125/EG, the European Commission has for the first time created a framework for the definition of product group-specific minimum requirements. The aim of the directive is to improve the environmental compatibility of energy-related products, taking into account the entire life cycle by setting eco-design requirements. Thus, the reference to eco-design need supports the advocates of a green growth position.

\subsection{Sharing Resources through Industrial Symbiosis}

Figure 8 shows the results of the life cycle impact assessment for each individual component of the industrial symbiosis. The results indicate that the environmental impact of the insect farming and the office buildings cause the largest negative environmental impact due to their consumption of non-renewable resources and energy. 


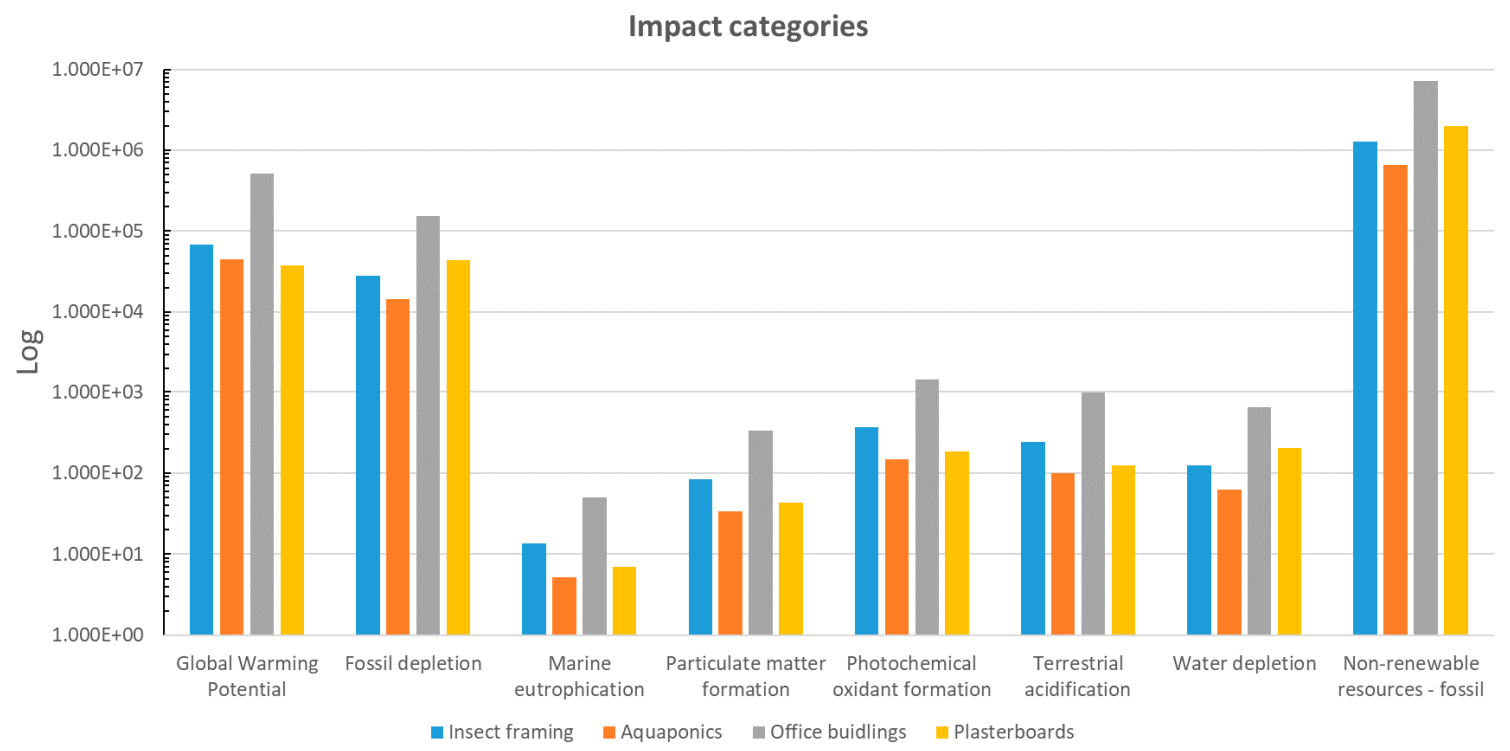

Figure 8. Results of the life cycle impact assessment for each component of the industrial symbiosis.

The results of the impact assessment for the industrial symbiosis in comparison to the sum of the individual resource use are shown in Figure 9. The principle of industrial symbiosis is part of industrial ecology and basically consists in the cooperation of different companies that (financially) benefit from each other being the motivation for the symbiosis. Business cooperation in industrial symbiosis is usually voluntary and, in most cases, geographically close and cross-industry or cross-sectoral. Conceptually, it represents the actual cooperation of the actors in a network of local and regional relations, not only to reduce the environmental impact as much as possible, but also to instigate a functioning (industrial) ecosystem.

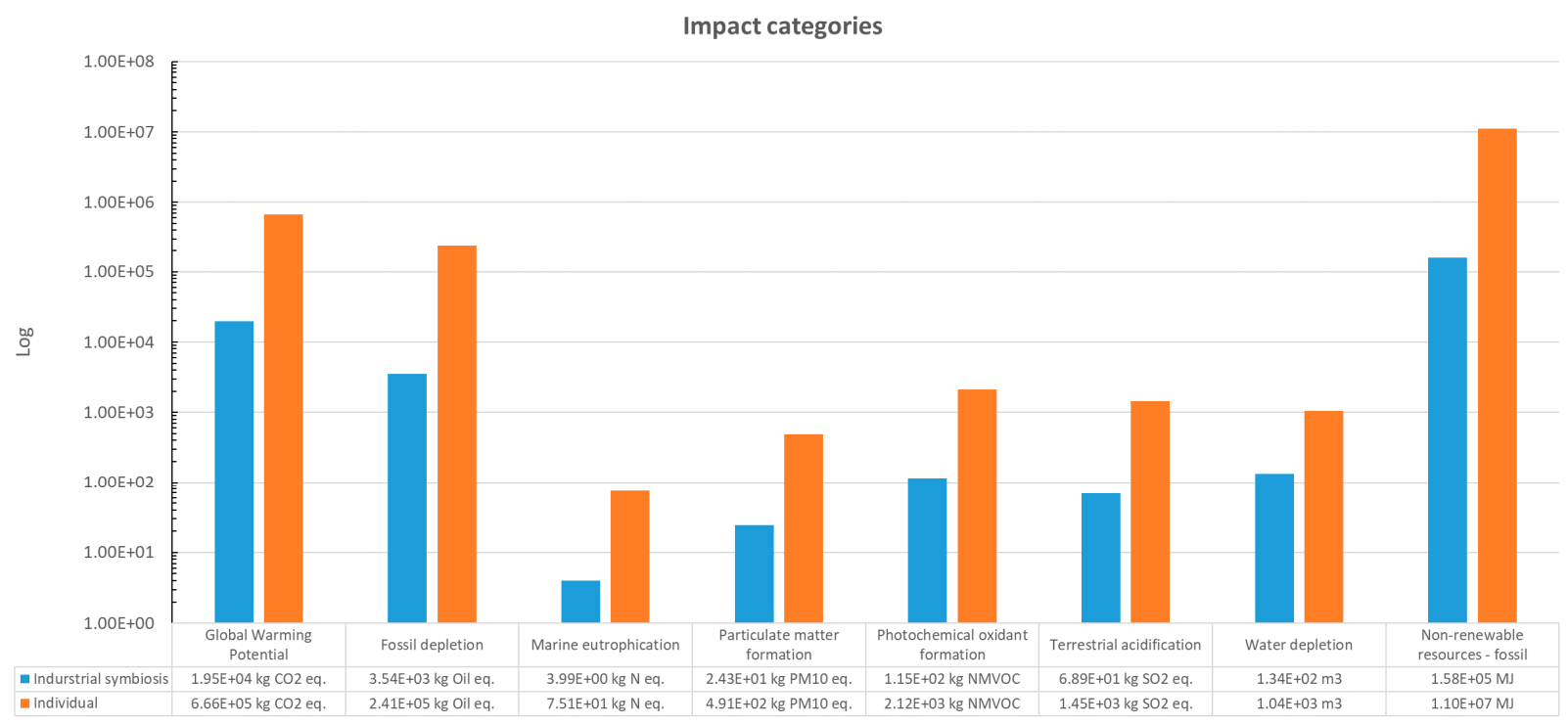

Figure 9. Results of the impact assessment for the industrial symbiosis in comparison to the sum of the individual resource use.

\section{Discussion}

An output stream (e.g., residues or waste) from one company can serve as an input stream (e.g., secondary raw material) for another company, or the excess waste heat can be made available as heat flow to another company. As a result, not only costs but also resources and energy can be 
saved and waste and emissions reduced. Thus, the formation of industrial symbioses contributes to ecological economic activity and improves the environmental performance of participating enterprises. As can be seen from the results in Figure 5, the results for the industrial symbioses show a decreased environmental impact in comparison to an individual resource use. The differences resulting in the resource savings reached up to 2 powers of ten, as can particularly be seen for the impact category fossil resource depletion. The impact categories climate change, fossil depletion and CED (cumulative energy demand) for non-renewable resources reached the highest values, as already observed in the calculations at the household level. This is mainly due to the amount of energy required at all process levels. Also, for the industrial symbiosis, a basic requirement is the use of renewable energies as energy source. As mentioned above, the aim of the LCA model is to show through a simplified example how the emissions change when material flows in the industrial symbiosis are optimized and factories are combined. The selected factories have intentionally been kept simple for illustration purposes. Therefore, the focus in the present investigation was on the assessment of the environmental impact along the life cycle and not on the process-engineering sequence. In the present stage, any effects or processes that might complicate such an analysis (like for instance rebound effects, the increased wear, the logistics overhead) have not yet been analyzed in the model. They must be subject to a later investigation stage as first of all the input data for such an analysis are established in the scientific community. Although some LCA investigations on industrial symbiosis do exist in scientific literature, the present investigation is the first one that considers innovative food production through insect farming.

According to the present investigation results, a sharing approach on the household as well on the company level leads to material and energy resource savings in terms of weight and volume. In the present case study of industrial symbiosis, it can be asked how the increased efficiency conditions, caused by the joint use of secondary raw materials affects price formation. As the use of secondary raw materials leads to the saving of primary resources, theoretically this could ultimately lead to a lower price of the products. Practically, this if often not the case as for recycling processes is usually needed a considerable amount of additional energy. In the case of industrial symbiosis, this disadvantage does not exist, since waste products without processing and transport become directly secondary raw materials for the secondary users. At this point, reference is made to a gap in the present analysis, which could not be sufficiently taken into account in the context of this investigation. Thus, consumer behavior and consumption patterns are not fully included. Within the framework of the objective of sustainable development, these play a decisive role. In 2016, Magno et al. [72] conducted a study on the motivation consumer behavior in a sharing-economy. They asked for the drivers for using online platforms for sharing-economy. The results showed that the use is above all ecologically motivated. The users are mainly focused on the reduction of emissions and the avoidance of waste that is finally the reduction of the personal ecological footprint. Recently, several studies have been carried out with similar results, e.g., Hamari et al. [73]. It requires the insight and sensitivity of consumers to opt for sustainable technologies, goods and services, to prefer concepts with low resource consumption or, for example, to get involved into item sharing. They ultimately generate the business case for sustainability [74]. They can not only decide what they consume, but whether they consume at all. Sufficiency is a crucial pillar of degrowth approaches. The time span between two consumption decisions usually ultimately determines a product's life time [8].

A third and final dimension to be included in the discussion is the role of policymakers in preserving scarce resources. In the present context, the reduction of planned obsolescence, which the authors consider to be practiced to date, needs to be addressed in particular. The results in Section 3.1 focus on the importance of the longevity of produced goods. The longevity determines, how effective product sharing approaches can operate as a whole. In the European Union, this subject was partially addressed through the requirements of the Ecodesign Directive (Directive 2009/125/EC). According to the sharing ideology, the focus is on the use of goods, which is why they wear out faster within collaborative consumption. If in the future the focus is no longer necessarily on ownership but on 
access according to Rifkin [15] to goods and services, it is also important that the more frequently used objects are more robustly designed.

\section{Conclusions}

Past and present resource use patterns have led to high environmental impact, environmental degradation and depletion of natural resources. Responsible resource use means not only the improvement of the resource efficiency in the production process but also sharing of secondary resources. In order to quantify resource saving effects in relation to the extent of environmental impacts, different forms of resource sharing arrangements have been investigated. The results of the two case studies indicated comparable resource consumption patterns: the main impact results from the use of fossil resources which leads to the depletion of the abiotic resource stock, particularly in case these resources are used linearly instead of a circular way. In the present case, this leads to an increase of the climate change impact as greenhouse gases are emitted as residues of the fossil resources use. The results further allow the conclusion that resource-sharing approaches are characterized through a large ecologic and economic potential, but also involving some risks. A comprehensive SWOT analysis of the sharing economy is not yet available and is a promising future research topic. The fact that scaling plays a decisive role in a sharing economy has become evident in the present investigation.

Pursuant to the existing types of industrial symbiosis (Eco-Industrial Parks (EIP), Eco-innovation Parks, Cradle to Cradle Business Innovation \& Improvement Zones etc.), the concept of industrial symbiosis also offers a further optimization potential in relation to industry -4.0 developments. In industry 4.0, production is intertwined with state-of-the-art information and communication technology. The driving force behind this development is the rapidly increasing digitalization of the economy and society. This changes the way in which future production and production is carried out. Intelligent factories (so-called "smart factories") determine the fourth industrial revolution and could practice the sharing of resources in an industrial symbiosis through smart grids. Tseng et al. [75] underlined the benefits of big data-driven industrial symbiosis. They propose mathematical and computer optimization models to provide decision-making support to optimize industrial symbiosis practices [75]. This kind of Industrial Symbiosis 4.0 might even be connected to electricity trading and power exchanges in order to optimize the energy consumption of sharing networks. The smart technology of the 21st century enables a radical new sharing economy that has the potential to revolutionize the entire way of life.

Supplementary Materials: Supplementary materials are available online at http:/ /www.mdpi.com/2071-1050/ 11/3/909/s1.

Author Contributions: The concept of the article was developed at the University of Applied Sciences Magdeburg-Stendal, section Ecological Engineering, by P.S. and L.F. in close collaboration with A.M. The Introduction was written by P.S. and L.F. The Methodology as well as the Results section were written by P.S. and A.M. The Discussion and Conclusion sections were written by all co-authors. The case studies were developed in close collaboration with all authors. All sections have been commented by the coauthors and include their views.

Funding: This research received no external funding.

Acknowledgments: We are grateful to the University of Applied Sciences Magdeburg-Stendal who awarded the 2018 Junior Research Prize to L. Folkens for his master thesis. Further, we are grateful to the TASIMA organizers, namely the Ministry of the Environment of Saxony-Anhalt, MHKW Rothensee GmbH, University of Applied Sciences Magdeburg-Stendal and Otto von Guericke University Magdeburg, who awarded the 2018 TASIMA Master Thesis Price to A. Meyer. Last but not least we cordially thank the Chamber of Commerce (IHK) Magdeburg, who awarded the 2018 IHK Research Price to T. Fauk. Finally, we thank the anonymous reviewers for their constructive suggestions.

Conflicts of Interest: The authors declare no conflict of interest. 


\section{References}

1. Asara, V.; Otero, I.; Demaria, F.; Corbera, E. Socially sustainable degrowth as a social-ecological trans-formation: Repoliticizing sustainability. Sustain. Sci. 2015, 10, 375-384. [CrossRef]

2. Kallis, G. In defence of degrowth. Ecol. Econom. 2011, 70, 873-880. [CrossRef]

3. Georgescu-Roegen, N. La décroissance: Entropie, Écologie, Économie, Nouvelle ed.; Éditions Sang de la terre: Paris, France, 1995.

4. Georgescu-Roegen, N. La Décroissance: Entropie, Écologie, Économie; Observatoire du Management Alternatif_Fiche de Lecture; Éditions Sang de la terre, Mastere Specialise Management du Developpement Durable HEC: Paris, France, 1995.

5. Petschow, U.; Lange, S.; Hofmann, D.; Pissarskoi, E.; aus dem Moore, N.; Korfhage, T.; Schoofs, A.; Ott, H. Gesellschaftliches Wohlergehen innerhalb planetarer Grenzen-Der Ansatz einer vorsorgeorientierten Postwachstumsposition, Zwischenbericht des Projektes "Ansätze zur Ressourcenschonung im Kontext von Postwachstumskonzepten" im Auftrag des Umweltbundesamtes Deutschland (Forschungskennzahl 3715 311040), ISSN: 1862-4804, Dessau-Roßlau, Oktober. 2018. Available online: https: / / www.google.de/url?sa=t\&rct=j\&q=\&esrc=s\&source=web\&cd=1\&cad=rja\&uact=8\& ved=2ahUKEwjPsuuo8vbeAhWNKVAKHcGCuEQFjAAegQICRAB\&url=https\%3A\%2F\%2Fwww. umweltbundesamt.de\%2Fpublikationen\%2Fvorsorgeorientierte-postwachstumsposition\&usg= AOvVaw3fX1TaMWINmVy5L2coj6JQ (accessed on 22 November 2018).

6. Jacobs, M.; Mazzucato, M. Rethinking Capitalism: An Introduction. In Rethinking Capitalism; Mazzucato, M., Jacobs, M., Eds.; John Wiley \& Sons Inc.: Chichester, UK, 2016; pp. 1-27.

7. Rockström, J.; Gaffney, O.; Rogelj, J.; Meinshausen, M.; Nakicenovic, N.; Schellnhuber, H.J. A roadmap for rapid decarbonization. Science 2017, 355, 1269-1271. [CrossRef] [PubMed]

8. Paech, N. Liberation from Excess. The Road to a Post-Growth Economy; Oekom Verlag: München, Germany, 2012; ISBN 978-3-86581-324-4.

9. Georgescu-Roegen, N. The Entropy Law and the Economic Process; Harvard University Press: Cambridge, MA, USA, 1971.

10. Jacob, M.; Edenhofer, O. Green growth, degrowth, and the commons. Oxf. Rev. Econ. Policy 2014, 30, 447-468. [CrossRef]

11. Worldbank. Inclusive Green Growth: The Pathway to Sustainable Development; The World Bank: Washington, DC, USA, 2012.

12. Hepburn, C.; Bowen, A. Prosperity with growth: Economic growth, climate change and environmental limits. In Handbook on Energy and Climate Change; Fouquet, R., Ed.; Edward Elgar Publishing: Cheltenham, UK, 2013.

13. Zhang, Z.; Xue, B.; Pang, J.; Chen, X. The Decoupling of Resource Consumption and Environmental Impact from Economic Growth in China: Spatial Pattern and Temporal Trend. Sustainability 2016, 8, 222. [CrossRef]

14. Benkler, Y.; Nissenbaum, H. Commons-based Peer Production and Virtue. J. Political Philos. 2006, 14, $394-419$. [CrossRef]

15. Rifkin, J. The Age of Access: The New Culture of Hypercapitalism, Where All of Life Is a Paid-for Experience; J.P. Tarcher/Putnam: New York, NY, USA, 2000.

16. Eichhorst, W.; Spermann, A. Sharing Economy-Chancen, Risiken und Gestaltungsoptionen für den Arbeitsmarkt. 2015. Available online: http://ftp.iza.org/report_pdfs/iza_report_69.pdf (accessed on 4 January 2019).

17. Demary, V. Competition in the Sharing Economy; IW Policy Paper Nr. 19/2015; Institut der deutschen Wirtschaft: Köln, Germany, 2015.

18. Wosskow, D. Unlocking the Sharing Economy. An Independent Review. 2014 . Available online: https:/ / www.gov.uk/government/uploads/system/uploads/attachment_data/file/378291/bis14-1227-unlocking-the-sharing-economy-an-independent-review.pdf (accessed on 4 January 2019).

19. Sundararajan, A. Peer-to-Peer Businesses and the Sharing (Collaborative) Economy: Overview, Economic Effects and Regulatory Issues. Written Testimony for the Hearing Titled 'The Power of Connection: Peer-to-Peer Businesses' at the United States House of Repre-Sentatives. 2014. Available online: http: / / smallbusiness.house.gov/uploadedfiles/1-15-2014_revised_sundararajan_testimony.pdf (accessed on 4 January 2019). 
20. Weber, T.A. Intermediation in a sharing economy: Insurance, moral hazard, and rent extraction. J. Manag. Inf. Syst. 2014, 31, 35-71. [CrossRef]

21. Institut für ökologische Wirtschaftsforschung (IÖW). Arbeitsberichte. 2018. Available online: https://www. peer-sharing.de/veroeffentlichungen/arbeitsberichte.html (accessed on 14 January 2019).

22. Ludmann, S. Ökologie des Teilens. Bilanzierung der Umweltwirkungen des Peer-to-Peer Sharing. 2018. Available online: https://www.peer-sharing.de/data/peersharing/user_upload/Dateien/Oekologie_des_ Teilens_Arbeitspapier_8_.pdf (accessed on 14 January 2019).

23. Berlina, A.; Lindberg, G.; Mikkola, N.; Smed Olsen, L.; Teräs, J. The Potential of industrial Symbiosis as a Key Driver of Green Growth in Nordic Regions; Johnsen, I.H.G., Ed.; Nordregio: Stockholm, Sweden, 2015; ISBN 978-91-87295-34-8.

24. McDonough, W.; Braungart, M. Cradle to Cradle: Remaking the Way We Make Things; North Point Press: New York City, NY, USA, 2002; p. 193, ISBN 0-86547-587-3.

25. Taranic, I.; Behrens, A.; Topi, C. Understanding the Circular Economy in Europe, from Resource Efficiency to Sharing Platforms: The CEPS Framework; CEPS Special Report, No. 143/July 2016; Centre for European Policy Studies (CEPS): Brussels, Belgium, 2016.

26. Cui, H.; Liu, C. Applying industrial symbiosis to chemical industry: A literature review. AIP Conf. Proc. 2017, 1864, 020090. [CrossRef]

27. Baldassarre, B.; Schepers, M.; Bocken, N.; Cuppen, E.; Korevaar, G.; Calabretta, G. Industrial Symbiosis: Towards a design process for eco-industrial clusters by integrating Circular Economy and Industrial Ecology perspectives. J. Clean. Prod. 2019. [CrossRef]

28. European Comission. Closing the Loop-An EU Action Plan for the Circular Economy; European Comission: Brussels, Belgium, 2015.

29. Chertow, M.R. “Uncovering” Industrial Symbiosis. J. Ind. Ecol. 2007, 11, 11-30. [CrossRef]

30. Chertow, M.; Park, J. Scholarship and Practice in Industrial Symbiosis: 1989-2014. In Taking Stock of Industrial Ecology; Clift, R., Druckman, A., Eds.; Springer: Cham, Switzerland, 2016.

31. United Nations Environment Programme (UNEP). Decoupling Natural Resource Use and Environmental Impacts from Economic Growth. Available online: https: / www.google.com/url?sa=t\&rct=j\&q=\&esrc= s\&source=web\&cd=2\&ved=2ahUKEwj1kZjZ6bLgAhXFFIgKHfjDCDIQFjABegQICRAC\&url=http \%3A \% 2F\%2Fwww.gci.org.uk\%2FDocuments\%2FDecoupling_Report_English.pdf\&usg=AOvVaw0eHO6ozp6E5vtc64o8_r9 (accessed on 10 February 2019).

32. Fischer-Kowalski, M. Entwicklung von Wirtschaftswachstum und Ressourcenverbrauch. Alpen-Adria-Universität Klagenfurt, Institut für Soziale Ökologie, Wien, Austria. 2008. Available online: https: / / www.google.de/url?sa=t\&rct=j\&q=\&esrc=s\&source=web\&cd=1\&ved=2ahUKEwiphpWIv_ reAhUH_aQKHfEtB7kQFjAAegQIABAC\&url=https\%3A\%2F\%2Fwww.wachstumimwandel.at $\%$ 2Fwp-content\%2Fuploads\%2Fpolicytargetsresourceuse_fischer-kowalski.ppt\&usg=AOvVaw12B517c4DvQ2DnoZ_9MS- (accessed on 22 November 2018).

33. United Nations Center for Regional Development. Contribution of 3Rs to achieving the Sustainable Development Goals-Science and Policy for the 2030 Sustainable Development Agenda (Background Paper for Plenary Session 1 of the Programme). In Proceedings of the Seventh Regional 3R Forum in Asia and the Pacific, Adelaide, SA, Australia, 2-4 November 2016.

34. Organisation for Economic Co-operation and Development, Working Party on Resource Productivity and Waste (OECD). Business Models for the Circular Economy-Opportunities and Challenges from a Policy Perspective. Available online: https:/ / www.google.com/url?sa=t\&rct=j\&q=\&esrc=s\&source=web\&cd= 1\&ved=2ahUKEwi52NbN67LgAhVTF4gKHaTPAjIQFjAAegQIARAC\&url=http\%3A\%2F\%2Fwww.oecd. org\%2Fenvironment \%2Fwaste\%2Fpolicy-highlights-business-models-for-the-circular-economy.pdf\& usg=AOvVaw3t5SfZdYw4DWsR914LhBJY (accessed on 10 February 2019).

35. McDougall, F.R.; White, P.; Franke, M.; Hindle, P. (Eds.) Integrated Solid Waste Management: A Life Cycle Inventory, 2nd ed.; Blackwell Science: Oxford, UK; Malden, MA, USA, 2001.

36. Allouche, J. The birth and spread of IWRM-A case study of global policy diffusion and translation. Water Altern. 2016, 9, 412-433.

37. Global Water Partnership (GWP). Integrated Water Resources Management; GWP: Stockholm, Sweden, 2000. 
38. UN-Water. The United Nations World Water Development Report 2: Water, a Shared Responsibility. World Water Assessment Programme (WWAP); Doc. no. UN-WATER/WWAP/2006/3; UNESCO: Paris, France; Berghahn Books: New York, NY, USA, 2006. Available online: http://unesdoc.unesco.org/images/0014/001444/ 144409e.pdf (accessed on 3 November 2017).

39. Douthwaite, B.; Ekboir, J.M.; Twomlow, S.; Keatinge, D. The concept of integrated natural resource management (INRM) and its implications for developing evaluation methods. In Natural Resource Management in Agriculture: Methods for Assessing Economic and Environmental Impacts; Shiferaw, B., Freeman, H.A., Swinton, S.M., Eds.; CABI Publishing: Oxfordshire, UK, 2004; pp. 321-340.

40. CGIAR Task Force on Natural Resource Management. Integrated Natural Resource Management Research in the CGIAR. A Brief Report on the INRM Workshop Held in Penang, Malaysia, 21-25 August 2000; CGIAR: Washington, DC, USA, 2000.

41. Hoff, H. Understanding the Nexus. Background Paper for the Bonn 2011 Conference: The Water, Energy and Food Security Nexus; Stockholm Environment Institute (SEI): Stockholm, Sweden, 2011.

42. UNU-FLORES. The Nexus Approach to Environmental Resources' Management. 2015. Available online: https: / / flores.unu.edu/en/research/nexus (accessed on 11 May 2018).

43. Hülsmann, S.; Ardakanian, R. (Eds.) White Book on Advancing a Nexus Approach to the Sustainable Management of Water, Soil and Waste; UNU-FLORES: Dresden, Germany, 2014.

44. Kurian, M.; Ardakanian, R. (Eds.) Governing the Nexus; Springer International Publishing: Cham, Switzerland, 2015.

45. Leck, H.; Conway, D.; Bradshaw, M.; Rees, J. Tracing the Water-Energy-Food Nexus: Description, Theory and Practice: Tracing the Water-Energy-Food Nexus. Geogr. Compass 2015, 9, 445-460. [CrossRef]

46. Avellan, T.; Roidt, M.; Emmer, A.; von Koerber, J.; Schneider, P.; Raber, W. Making the Water-Soil-Waste Nexus work: Framing the boundaries of resource flows. Sustainability 2017, 9, 1881. [CrossRef]

47. McLellan, B.C. The Minerals-Energy Nexus: Past, Present and Future. In Sustainability through Innovation in Product Life Cycle Design, EcoProduction; Matsumoto, M., Masui, K., Fukushige, S., Kondoh, S., Eds.; Springer: Tokyo, Japan, 2017; pp. 619-631.

48. Halloran, A.; Hanboonsong, Y.; Roos, N.; Bruun, S. Life cycle assessment of cricket farming in north-eastern Thailand. J. Clean. Prod. 2017, 156, 83-94. [CrossRef]

49. Halloran, A.; Roos, N.; Eilenberg, J.; Cerutti, A.; Bruun, S. Life cycle assessment of edible insects for food protein: A review. Agron. Sustain. Dev. 2016, 36, 57. [CrossRef]

50. Oonincx, D.G.A.B.; de Boer, I.J.M. Environmental impact of the production of mealworms as a protein source for humans-A life cycle assessment. PLoS ONE 2012, 7, e51145. [CrossRef] [PubMed]

51. Roffeis, M.; Muys, B.; Almeida, J.; Mathijs, E.; Achten, W.; Pastor, B.; Velásquez, Y.; Martinez-Sanchez, A.; Rojo, S. Pig manure treatment with housefly (Musca domestica) rearing-An environmental life cycle assessment. J. Insects Food Feed 2015, 1, 195-214. [CrossRef]

52. Van Zanten, H.H.; Mollenhorst, H.; Oonincx, D.G.; Bikker, P.; Meerburg, B.G.; De Boer, I.J. From environmental nuisance to environmental opportunity: Housefly larvae convert waste to livestock feed. J. Clean. Prod. 2015, 102, 362-369. [CrossRef]

53. Boons, F.; Spekkink, W.; Mouzakitis, Y. The dynamics of industrial symbiosis: A proposal for a conceptual framework based upon a comprehensive literature review. J. Clean. Prod. 2011, 19, 905-911. [CrossRef]

54. Boons, F.; Spekkink, W.; Jiao, W.T. A process perspective on industrial symbiosis theory, methodology, and application. J. Ind. Ecol. 2014, 18, 341-355. [CrossRef]

55. Von Hauff, M. Industrial Ecology Management: Nachhaltige Entwicklung Durch Unterneh-Mensverbünde; Springer Gabler: Wiesbaden, Germany, 2012; ISBN 978-3834923615.

56. Von Koerber, J. Concept for the resource-efficient use of water using the example of the development of Eco Industrial Parks in Iran. Master's Thesis, University of Applied Sciences Magdeburg-Stendal, Magdeburg, Germany, 2016. (In German)

57. Cui, H.; Liu, C.; Côté, R.; Liu, W. Understanding the Evolution of Industrial Symbiosis with a System Dynamics Model: A Case Study of Hai Hua Industrial Symbiosis, China. Sustainability 2018, 10, 3873. [CrossRef]

58. Marchi, B.; Zanoni, S.; Zavanella, L.E. Symbiosis between industrial systems, utilities and public service facilities for boosting energy and resource efficiency. Energy Procedia 2017, 128, 544-550. [CrossRef] 
59. Smetana, S.; Palanisamy, M.; Mathys, A.; Heinz, V. Sustainability of insect use for feed and food: Life Cycle Assessment perspective. J. Clean. Prod. 2016, 137, 741-751. [CrossRef]

60. Henger, R.; Deschermeier, P.; Hude, M.; Seipelt, B.; Voigtländer, M. Energieeffizienz bei Büroimmobilien: Dena-Analyse über den Gebäudebestand und Seine energetische Situation; Deutsche Energie-Agentur GmbH: Berlin, Germany, 2016.

61. Boogman, P. Gipsplatten (RIGIPS RB, RIGIPS RF, RIGIPS RBI, RIGIPS RFI, RIGIPS DL, RIGIPS DLI und RIGIPS Riduro): Saint-Gobain Rigips Austria GesmbH; IBO Österreichisches Institut für Bauen und Ökologie GmbH: Vienna, Austria, 2014.

62. Fauk, T. Anlagenkonzept zur Zucht von Insekten mit Ziel der Produktion von Futter-, Nahrungs- und Düngemitteln in urbanen Brachen am Beispiel einer ehemaligen Filiale des Lebensmitteleinzelhandels am Standort Niederndodeleben. Bachelor Thesis, University of Applied Sciences Magdeburg-Stendal, Magdeburg, Germany, 2018.

63. Meyer, A. Dezentrale Energieversorgung für das Urban Farming-Energieversorgung und Speicherung für ein Aquaponiksystem am Standort Magdeburg. Master's Thesis, University of Applied Sciences Magdeburg-Stendal, Magdeburg, Germany, 2018.

64. Plat, K. Untersuchung von Potenzialen für urbane Landwirtschaft in Magdeburg. Master's Thesis, University of Applied Science Magdeburg-Stendal, Magdeburg, Germany, 2018.

65. Bernstin, S. Aquaponic Gardening: A Step-By-Step Guide to Raising Vegetables and Fish Together; New Society Publishers: Gabriola Island, BC, Canada, 2011.

66. Engelmann, B. Thermische Behandlung. 2016. Available online: https://www.umweltbundesamt.de/ themen/abfall-ressourcen/entsorgung/thermische-behandlung\#textpart-1 (accessed on 14 November 2018).

67. Fehrenbach, H.; Giegrich, J.; Mahmood, S. Beispielhafte Darstellung Einer Vollständigen, Hochwertigen Verwertung in Einer MVA unter Besonderer Berücksichtigung der Klimarelevanz; Umweltbundesamt: Dessau-Roßlau, Germany, 2007.

68. Daniel-Gromke, J. Anlagenbestand Biogas und Biomethan-Biogaserzeugung und -nutzung in; DBFZ Deutsches Biomasseforschungszentrum: Leipzig, Germany, 2017.

69. Klinski, S. Studie: Einspeisung von Biogas in das Erdgasnetz; Fachagentur Nachwachsende Rohstoffe e.V.: Gülzow, Germany, 2006.

70. Paschotta, R. Methan. 2018. Available online: https://www.energie-lexikon.info/methan.html (accessed on 14 November 2018).

71. Schmederer, J. infoBlätter Kreislaufwirtschaft: Gipsplatten und mehr; Bayerisches Landesamt für Umwelt: Augsburg, Germany, 2017.

72. Magno, F.; De Boer, M.; Bentoglio, B. Sharing economy: Comparing users and non-users perception. 19th Toulon-Verona International Conference. Huelva. 2016. Available online: http:/ / sites.les.univr.it/eisic/wpcontent/uploads/2018/07/Magno-De-Boer-Bentoglio.pdf (accessed on 4 January 2019).

73. Hamari, J.; Sjöklint, M.; Ukkonen, A. The Sharing Economy: Why People Participate in Collaborative Consumption. J. Assoc. Inf. Sci. Technol. 2015, 67, 2047-2059. [CrossRef]

74. Schaltegger, S.; Lüdeke-Freund, F. The "Business Case for Sustainability" Concept. A Short Introduction; Centre for Sustainability Management, Leuphana University: Lüneburg, Germany, 2012; ISBN 978-3-942638-22-7.

75. Tseng, M.-L.; Tan, R.R.; Chiu, A.S.F.; Chien, C.-F.; Kuo, T.C. Circular economy meets industry 4.0: Can big data drive industrial symbiosis? Resour. Conserv. Recycl. 2018, 131, 146-147. [CrossRef]

(C) 2019 by the authors. Licensee MDPI, Basel, Switzerland. This article is an open access article distributed under the terms and conditions of the Creative Commons Attribution (CC BY) license (http://creativecommons.org/licenses/by/4.0/). 